\title{
The obese gut microbiome across the epidemiologic transition
}

\author{
Lara R. Dugas ${ }^{*}$, Miles Fuller², Jack Gilbert ${ }^{3,4,5,6}$ and Brian T. Layden ${ }^{2,7}$
}

\begin{abstract}
The obesity epidemic has emerged over the past few decades and is thought to be a result of both genetic and environmental factors. A newly identified factor, the gut microbiota, which is a bacterial ecosystem residing within the gastrointestinal tract of humans, has now been implicated in the obesity epidemic. Importantly, this bacterial community is impacted by external environmental factors through a variety of undefined mechanisms. We focus this review on how the external environment may impact the gut microbiota by considering, the host's geographic location 'human geography', and behavioral factors (diet and physical activity). Moreover, we explore the relationship between the gut microbiota and obesity with these external factors. And finally, we highlight here how an epidemiologic model can be utilized to elucidate causal relationships between the gut microbiota and external environment independently and collectively, and how this will help further define this important new factor in the obesity epidemic.
\end{abstract}

Keywords: Obesity, Gut microbiome, Geographical differences

\section{Background}

In 2014, the World Health Organization (WHO) estimated that approximately half a billion adults were obese, a doubling in the prevalence since 1980 [1]. Considering this statistic, the obesity epidemic is a global health issue, impacting both the industrialized and developing world $[2,3]$, where the societal impact is felt through the multitude of comorbidities occurring with obesity including type 2 diabetes $[4,5]$, nonalcoholic fatty liver disease [6] and cardiovascular diseases $[7,8]$. These medical complications and the international socioeconomic implications are considerable motivations for investigating the epidemic. The goal of this review is to provide a novel epidemiologic perspective of viewing and studying the global obesity epidemic, in light of the newly discovered factor, the gut microbiota.

Obesity is defined as excess adiposity where an imbalance in two processes; caloric intake and physical activity levels, are thought to be the key drivers [9,

\footnotetext{
*Correspondence: Idugas@luc.edu

1 Public Health Sciences, Stritch School of Medicine, Loyola University

Chicago, 2160 S. 1st Ave, Maywood, IL 60153, USA

Full list of author information is available at the end of the article
}

10]. Genetic and environmental factors impact both these two processes through complex mechanisms [11]. Genome wide association studies have been helping us untangle this complex genetic landscape for over a decade [12]; however, genetic polymorphisms alone do not explain the obesity epidemic. Many environmental factors contribute to the obesity epidemic, where these environmental factors are related and definable largely by the geographical location of the individual, as the location defines many influences of the obesity epidemic (such as diet and physical activity). As compared to our genetics which could not have changed dramatically over the time period that the obesity epidemic has emerged, many key environmental factors have been altered over this timeframe, most notably shifts in diet and physical activity habits and patterns [3, 13], and others factors including the rise of the built environment [14], social and economic factors [15], environmental endocrine disruptors [16], and co-morbid medical conditions [17]. Interestingly, some of these environmental factors interact with our genes through epigenetic mechanisms [18]. One example, as reported by Rosenquist et al. [19], where significant gene-by-birth cohort interactions with the FTO variant (rs993609) occurred, was observed by 
using longitudinal data from the Framingham study, were the genetic impact of this variant on BMI over time, indicates the influence of the changing environmental factors. Taken together, genetic and environmental factors are driving the obesity epidemic through complex interactions.

Recently, a new environmental factor, the gut microbiota (defined as microbes that live in the gastrointestinal tract) has been implicated as a factor in the obese phenotype [20-27]. This novel factor is an ecosystem in itself, comprised of 500-1000 species per person, and the sum genetic potential of these diverse assemblages can exceed 100 fold the number of human genes [28, 29]. This results in many of these bacterial genes having unique functions that complement the genetic repertoire of humans [30]. Of importance, until recently scientists have found it challenging to study the gut microbiota, as many of these organisms cannot be grown in culture, thus limiting our ability to investigate their individual physiological and metabolic potential. The advent of new genetic sequencing approaches has enabled us to describe the diversity and functional potential of these assemblages. Metagenomic approaches, particularly, enable the functional potential of the assemblage to be linked to its phylogenetic composition. Because of the advances in sequencing approaches, the gut microbiota is now approachable to be studied [31,32].

As the gut microbiota appears to be influenced by many external factors in the host's environment [33], investigation of this microbial ecosystem in relation to other influencing external factors is needed [34, 35]. Thus, studying this internal ecosystem independently and relative to external factors in the obesity epidemic is needed, and will help us understand the nature of the obesity epidemic and the novel role of the gut microbiome. As the geographical location of the host defines many of these external factors that influence the gut microbiota, we systematically explore this topic (1) by providing background on how human geography is related to the obesity epidemic ('Human Geography and Obesity'), (2) assessing the literature on the gut microbiota relative to one's geography ('Gut Microbiota and Geography') (3) describing the key studies relating the gut microbiota to obesity ('Gut Microbiota and Obesity') and finally, (4) other key related factors in this interaction with the obese gut microbiota ('Human Geography, Diet and Physical Activity, and the Obesity-Associated Microbiota'). Moreover, this review provides a rationale for employing a global epidemiologic model for studying the associations between the gut microbiota and the development of obesity, which allows capturing geographical diverse external environmental factors.

\section{Human geography and obesity}

Human geography, as defined by a particular group of individuals in a location, has unique relationship to obesity. In large part, this interaction of human geography with obesity is related to the development status of the people within this geographic location. For example, the burden of the obesity epidemic is felt most in developed countries [36, 37], and is related to the human development index (HDI) of the country. This index is a United Nations Index describing the level of development of that population/country [38].

Exemplifying this, one of the first large multi-country cohort studies, initiated in the early 1990's, titled "The International Collaborative Study on Hypertension in Blacks" [39, 40], recruited over 9000 adults living in seven countries, including the US (urban Chicago), Africa (rural and urban Nigeria and Cameroon), and the Caribbean (Jamaica, Barbados, and St. Lucia), and found the prevalence of obesity ranged from approximately $1 \%$ in African cohorts to $36 \%$ in the US [41, 42]. More recently (2010-2013), we conducted a large multi-country study following a cohort of 2500 young adults of African descent from five countries in the Modeling the Epidemiologic Transition Study (METS). Participants were from the US (urban), Ghana (rural), South Africa (peri-urban), Jamaica (urban) and the Seychelles (urban) [2]. We found that the prevalence of obesity in adults of African origin continues to mostly present in a continuum reflecting each countries HDI ranking, i.e. lowest in Ghana and highest in the US. In METS, the prevalence of obesity ranges from $1.4 \%$ in Ghanaian men to $64 \%$ in US women [2]. While the prevalence of obesity has increased among all of the METS research sites, it has more than doubled among US men and increased from 42 to $67 \%$ among the women sampled from the same urban US community over a 15 year time period (unpublished data). Ezzati et al. [43], using data from over 100 countries, found that the relationship between BMI and country stage of development was best captured using a U-shaped association, and that the rate of increasing BMI change was greatest in countries moving from low to middle development, compared to countries moving from middle to high development [43]. In fact, we have demonstrated that adults residing in Jamaica, a rapidly transiting country, experienced significantly more weight gain compared to adults living in either the USA or Nigeria over a 4 year period between 1995 and 1999 supporting this U-shaped relationship [44]. Consistent with this model, we have shown that the prevalence of obesity-related chronic disease, including hypertension $[42,45]$ and type 2 diabetes [46-48] in blacks of the African diaspora occurs in manner related to the resident countries HDI. Consequently, 
studying different populations allows us to identify these populations with changing rates of obesity and related co-morbidities. Taken together, these data indicate the country-level stage of economic development has a strong association with the population-level prevalence of obesity.

\section{Gut microbiota and geography}

Some studies have begun to investigate the similarities and differences in the gut microbiota across populations $[29,49,50]$. In one of the first studies to examine this, Karlsson et al. [29] attempted to identify if a common gut microbiome exists across populations, where in this study, they examined 782 persons from four studies, spanning three different continents (Europe, USA and China). Overall, it was observed that differences in species, gene richness and diversity existed across populations, but that a common gut microbiome was shared, with approximately half a million microbial genes between studies (see Table 1A; Fig. 1). Another study, examining a range of individuals from birth to 70 years in populations of Venezuela, Malawi, and United States [49], found that the gut microbiota of each population had distinct overall phylogenetic composition. Looking at the collective microbiome, assessed through metagenomic shotgun sequencing of a subset of this group (110 of the 531 total individuals that had bacterial species determined), unique patterns of over and under-repressed genes was observed between populations [49]. Further, recent evidence has suggested that even visits of short duration to other geographic locations can influence the gut microbial assemblage; specifically a month long visit to Bangkok, Thailand, can dramatically influence the microbial composition of one participant's microbiome [51]. Collectively these data indicate while shared features in the gut microbiota may exist across populations, large differences exists across populations.

While not exhaustive, these studies exemplify a simple observation, that microbial assemblages associated with the human intestinal tract are not homogeneous throughout the world. Additionally, certain microbial phylogenetic characteristics are likely globally shared on some level; however, specific genetic signatures selected for by local environmental characteristics undoubtedly occurs in geographically disparate environments. Moreover, within each population exist lifestyle factors such as diet, and physical activity which are likely influencing the observed differences in microbial community structure across different geographic environments. Thus, rather than geographic location itself driving microbial patterns, it is possible that geography is a proxy for these factorial influences.

\section{Gut microbiota and obesity}

The human gut microbiome has been linked to the obesity epidemic [24, 52-55]. However, animal studies comprise the majority of causative evidence linking changes in microbial composition to the obesity phenotype (see Table 1B). In seminal rodent-based work by Backhed et al. [52], the gut microbiota was observed to regulate the host's ability to harvest energy from food, thus showing its role in host fat storage [52]. Subsequent experiments suggest that gut microbiota are affected by adiposity (with higher ratios of Firmicutes to Bacteroidetes in ob/ob mice [23]. Further work has established the potential for a particular gut microbiota ecosystem to impart an obesity phenotype, where the microbiota of ob/ob (a genetic model of obesity) or lean mice where transferred to germ-free mice [20]. It was also observed that the colonization of germ-free mice with ob/ob mouse-associated gut microbiota resulted in greater weight gain and energy extraction than the colonization with lean mouse-associated gut microbiota [21]. Providing further direct evidence for the existence of a transmissible obesity microbiota, Ridaura et al. [22] transplanted uncultured gut microbiota collected from feces from adult female twin pairs, discordant for obesity into germ-free mice fed the same diets. Mice receiving the obesity gut microbiota experienced significantly greater increases in adiposity. It was also noted that the fecal biomass from the lean mice was significantly greater compared to the fecal biomass from the obese siblings. It should also be noted that changes in phyla are not always a result of obesity per se, but may simply be a reflection of the macronutrient composition changes [56].

In humans, the data are more variable, but overall most studies indicate an increase in the Firmicutes and a decrease in the Bacteroidetes phyla to be associated with obesity [20,54], although not all studies have observed this $[55,57]$. Yet, in one of the earliest human studies, Ley et al. [20] compared the gut microbiota of 12 obese individuals, following two different low calorie diets over the period of 1 year and found that at baseline, obesity was associated with fewer Bacteroidetes $(\mathrm{p}<0.001)$. However, with subsequent weight loss, there were increases in the Bacteroidetes, concomitant with decreases in the Firmicutes phyla, and thus an increased Bacteroidetes/Firmicutes ratio, irrespective of diet assignment. Ferrer et al. [54] confirmed these findings comparing the gut microbiota in lean and obese individuals. However, as noted in a review by Bell [58], whether the human gut microbiota is causing obesity is not clear.

Some studies have attempted to address this challenging question. Vrieze et al. [59] did investigate the effect of transferring human gut microbiota from healthy lean 
Table 1 Key studies describing the gut microbiota and its relationship to different geographical locations (A), and key studies describing the gut microbiota and its relationship to obesity (B) are indicated

\begin{tabular}{|c|c|c|}
\hline Author & Groups & Geographical effect \\
\hline \multicolumn{3}{|l|}{ A } \\
\hline De Filippo et al. [77] & Rural Africa vs. Italian children (1-6 years) & $\begin{array}{l}\text { Species differences existed that conferred specific nutritional } \\
\text { effects }\end{array}$ \\
\hline Lee et al. [50] & $\begin{array}{l}\text { Monozygotic and dizygotic US vs. Korean twins, either normal } \\
\text { weight }\left(\mathrm{BMI}<25 \mathrm{~kg} / \mathrm{m}^{2}\right) \text { or overweight }\left(\mathrm{BMI}>25 \mathrm{~kg} / \mathrm{m}^{2}\right)\end{array}$ & $\begin{array}{l}\text { Significant differences in configuration fecal communities } \\
\text { between sites }\end{array}$ \\
\hline $\begin{array}{l}\text { Yatsunenko et al. } \\
\text { [49] }\end{array}$ & $\begin{array}{l}\text { Venezuelan (Amerindians), Malawian, US children (0-17 years) } \\
\text { and adults ( } 18-70 \text { years) }\end{array}$ & Phylogenetic and microbiota enzymatic differences \\
\hline Tyakht et al. [81] & Urban vs. rural Russian males and females ( $14-85$ years) & Phylogenetic differences existed \\
\hline Karrlson et al. [28] & $\begin{array}{l}\text { Type } 2 \text { diabetes, normal- and impaired-glucose tolerance } \\
\text { older European women (>70 years) vs. type } 2 \text { diabetes, } \\
\text { normal and impaired glucose tolerance Chinese men and } \\
\text { women (13-86 years) }\end{array}$ & Metagenomic cluster differed between two populations \\
\hline David et al. [51] & Two US adult males (26, and 36 years) & Travel acutely altered phylogenetic taxa \\
\hline Author & Groups & Obesity effect \\
\hline \multicolumn{3}{|l|}{ B } \\
\hline Backhed et al. [52] & $\begin{array}{l}\text { Conventionally raised vs. germ-free and germ-free conven- } \\
\text { tionalized }\end{array}$ & $\begin{array}{l}\text { Conventional had significantly more body fat than germ-free, as } \\
\text { did conventionalized, both eating less chow }\end{array}$ \\
\hline Ley et al. [30] & Lean vs. obese humans & Relative proportion of Bacteroidetes is reduced in obesity \\
\hline $\begin{array}{l}\text { Turnbaugh et al. } \\
\text { [21] }\end{array}$ & Ob/ob mice vs. ob/+ and $+/+$ mice & $\begin{array}{l}\text { Ob/ob mice increased rate of energy harvest from diet, } \\
\text { transmission of ob/ob gut microbiome to }+/+ \text { resulted in } \\
\text { significantly greater increase in body fat }\end{array}$ \\
\hline $\begin{array}{l}\text { Turnbaugh et al. } \\
\text { [24] }\end{array}$ & $\begin{array}{l}\text { Lean }\left(\mathrm{BMI}<25 \mathrm{~kg} / \mathrm{m}^{2}\right) \text { and overweight }\left(\mathrm{BMI} \geq 25 \mathrm{~kg} / \mathrm{m}^{2}\right) \text { or } \\
\text { obese }\left(\mathrm{BMI} \geq 30 \mathrm{~kg} / \mathrm{m}^{2}\right) \text { twins }\end{array}$ & $\begin{array}{l}\text { Lower proportion Bacteroidetes and higher proportion of Act- } \\
\text { inobacteria in obese vs. lean twins. No difference in Firmicutes } \\
\text { between twins }\end{array}$ \\
\hline $\begin{array}{l}\text { Turbbaugh et al. } \\
\text { [25] }\end{array}$ & $\begin{array}{l}\text { Germ-free mice colonized with human gut microbiota, fed } \\
\text { either low-fat, plant polysaccharide-rich or high fat (West- } \\
\text { ern) diet }\end{array}$ & $\begin{array}{l}\text { Increase in proportion of Firmicutes and decrease in proportion } \\
\text { of Bacteroidetes in mice fed western diet. Off-spring from } \\
\text { either germ-free or humanized mice indicated gut microbi- } \\
\text { ome could be transmitted, sharing } 83 \% \text { of class-level Taxa } \\
\text { and } 73 \% \text { genus level }\end{array}$ \\
\hline Murphy et al. [56] & Ob/ob mice vs. wild type on high- or low-fat diet & $\begin{array}{l}\text { Increase in Firmicutes in high-fat and ob/ob. Reduction in } \\
\text { Bacteroidetes in ob/ob only }\end{array}$ \\
\hline Lee et al. [50] & US vs Korean & Lower alpha-diversity in obesity, regardless of site \\
\hline Ridaura et al. [22] & $\begin{array}{l}\text { Germ-free mice transplanted with fecal microbiota from twins } \\
\text { discordant for obesity (obese twin } \mathrm{BMI} \geq 30 \mathrm{~kg} / \mathrm{m}^{2} \text { ) }\end{array}$ & $\begin{array}{l}\text { Mice receiving obese fecal microbiota had significantly greater } \\
\text { increase in adipose mass. Feces from mice with obese fecal } \\
\text { microbiota had higher branched chain amino acids }\end{array}$ \\
\hline
\end{tabular}

individuals $\left(\mathrm{BMI}<23 \mathrm{~kg} / \mathrm{m}^{2}\right)$ into male participants with the metabolic syndrome. Participants were either infused with the healthy gut microbiota $(\mathrm{N}=9)$ or reinfused with their own gut microbiota $(\mathrm{N}=9)$. Prior to infusion, the gut microbiota from the obese participants was characterized by an overabundance of Bacteroidetes, and lower microbial diversity compared to the lean healthy donors. Importantly, peripheral insulin sensitivity was measured before and repeated 6 weeks after the gut microbiota infusion and found to significantly increase in those participants receiving the healthy microbiota. While not answering the relationship of the gut microbiota to obesity, these data suggest a causal role of the gut microbiota in insulin sensitivity.

As such many postulated mechanisms of how the gut microbiota contributes to obesity through dysbiosis have been suggested [21, 60-63] including increased energy harvest by the obese microbiome or diet-induced changes in the gut microbiome leading to low levels of gut and systemic inflammation [60-62]. Examples of this later mechanism comes from Ding et al. [63], who reported that a combination of a high fat diet and gut microbiota induced intestinal inflammation and weight gain in mice. Similarly, Cani et al. [61] showed that following prebiotic administration, mice exhibited lower plasma cytokines as well as hepatic and oxidative stress markers as a result of prebiotic alterations in the gut microbiota. While these rodent studies are compelling, our basic understanding of our gut microbiota ecosystem remains incomplete, and multiple other mechanisms may be involved [58, 6467], particularly in humans. 


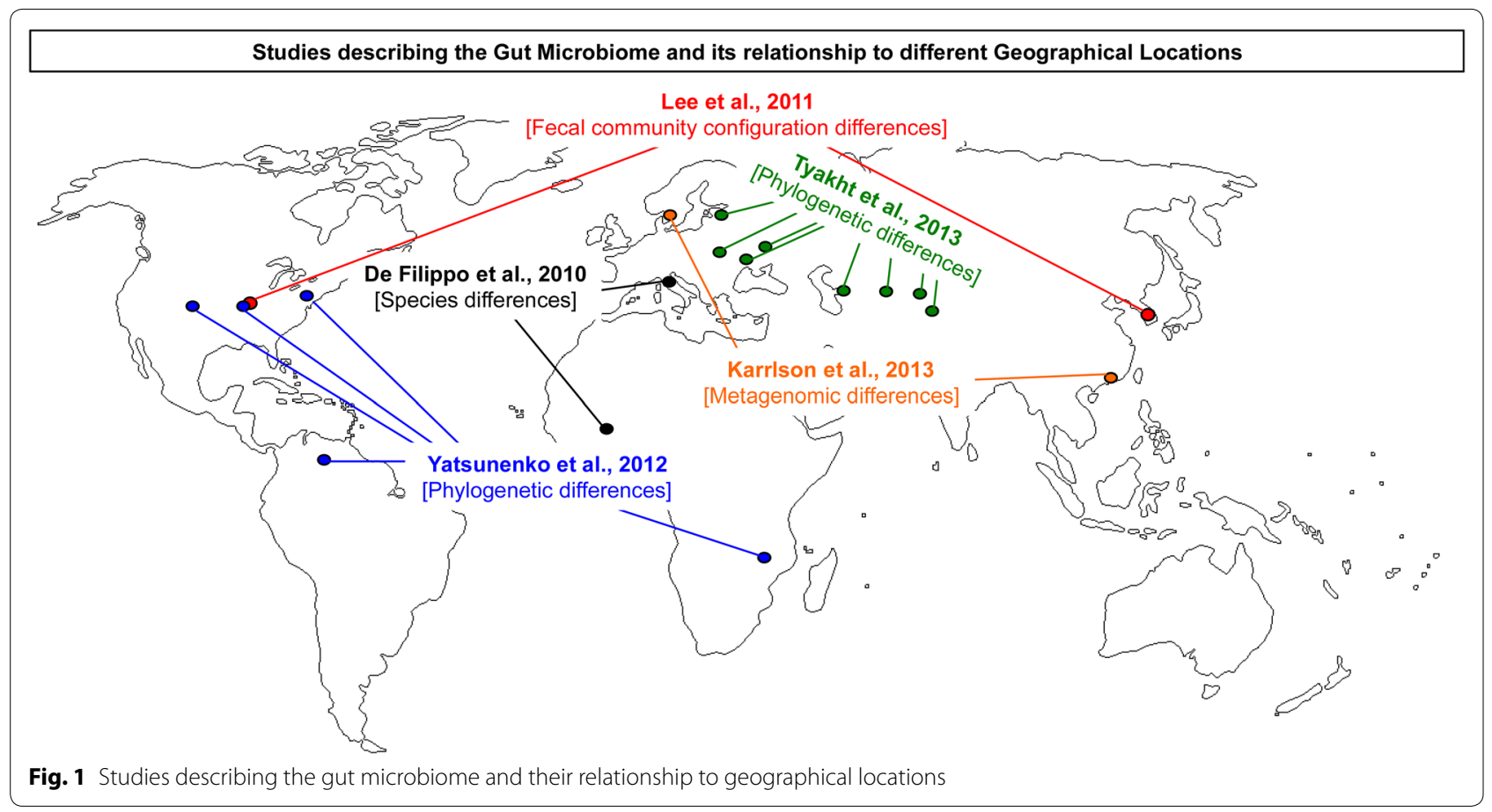

\section{Human geography, diet, and physical activity, and the obesity-associated microbiota}

Very few studies have explicitly examined the interaction of human geography, microbial community structure and obesity. However, one provocative study invokes Bergmann's rule, that humans are heavier in higher latitudes compared to lower latitudes, and suggests that this may be the result of the functional ability of the microbiome to extract energy from food [68]. The authors of this study cite the higher Firmicutes to Bacteroidetes ratio in high latitude populations as evidence for this relationship. Another study by Arumugun et al. [57] using DNA sequence homology to examine phylogenetic composition found significant variation among 39 individuals from six different countries. Analyses revealed three distinct profiles among the six different nations represented; identifiable by the variation in the levels of one of three genera: Bacteroides, Prevotella and Ruminococcus. The authors, however, could not account for any generaderived BMI effects in these samples, but did find phylogenetic differences which suggested that the variation in the dominance of each phyla among the countries reflected different routes to generate energy from the fermented substrates in the gut.

Next, we examine more local environmental factors, such as diet and physical activity behaviors, and how these factors contribute to these relationships. Overall, diet-related microbiome associations $[69,70]$ have been more extensively studied; whereas, only a handful of studies have explored physical activity associations with the microbiota composition [71-75]. It is well described that the human microbiome is, in part, a reflection of the host's diet, as exemplified by shifts in the infant microbiome following the introduction of solid food [76]. Specifically, this shift usually occurs between 18 and 36 months of age and was demonstrated by De Filippo et al. [77] who compared gut microbiota in healthy children, aged 1-6 years of age and either living in Italy or rural Burkina Faso. Interestingly, the average fiber content in the children from Burkina Faso was approximately 10-14 g/ day versus $6-8 \mathrm{~g} /$ day in the Italian children and this difference in fiber and resistant starch intake was shown to result in Burkina Faso children to have greater levels of short-chain fatty acids in their fecal samples, than Italian children, and also reflected in different ratios of Firmicutes and Bacteriodetes between groups. Indeed other studies manipulating dietary resistant starch in the short term appear to result in greater changes in the gut microbiota compared to other dietary manipulations [78].

These results support other studies reporting that an individual's dietary habits shape their microbial community and that this core community remains relatively stable during the host life span. Voreades et al. [70] reviewed several geographical studies comparing children and adults living in Malawi, and Venezuela, to participants living in the US [49], children living in India and the US [79] and finally South African and US African American adults [80] and collectively reported 
significantly different microbial communities, in part, as a result of differences in the macronutrient composition of the host's diet [70]. Notably among the populations living outside of the US (Africans), where the diets are not as rich in protein and fat intake, there is an abundance of bacteria associated with resistant starches such as the Prevotella genus, as compared to US African Americans [80]. Schnorr et al. [69] reported that in traditional adult African hunter gathers living in Tanzania (Hadza), there was higher microbial richness and biodiversity compared to urban Italian adults, and their dietary habits were quite distinct (either hunter-gather related diet vs domestic farming, respectively). In another study examining urban vs rural individuals, microbial communities in stool samples of 50 adults from metropolitan and 46 adults from rural areas of Russia, using shotgun metagenomics, demonstrates that rural populations had a predominance of taxa associated with a 'healthy gut', which again mostly comprised differences in taxa associated with Firmicutes and Bacteroidetes [81]. The diets of the rural individuals were more in line with dietary data from populations living in developing countries compared to the diets of the urban samples, which were categorized by a reduced consumption of resistant starches, typically associated with the Western diet [81]. And finally, in a report examining the stool-associated microbiome of children from Europe and rural Africa, it was observed that significant correlations occurred with diet, whereby dietary fiber was a key driver of microbial differences between these geographically disparate cohorts [77].

Physical activity training has been shown to have significant, beneficial effects on the gut microbiota, by increasing the gut microbiota diversity and improving the ratio between certain bacterial genera [82]. One of the first studies to explore exercise-induced changes in microbial community structure found that in rats, voluntary training when compared to sedentary controls, significantly influenced the diversity of the microbiome [74], and also indicated that exercise enriched the cecum with butyrate-producing bacteria. In another report, Pertriz et al. [71] used obese and hypertensive rats and a treadmill running protocol, to expose rats to 4 weeks of exercise training program ( 5 days a week, for $30 \mathrm{~min}$ per day). Following the exercise training, both the obese and hypertensive rats showed increased microbiota diversity, associated with an increase in the relative abundance at the genus level in all rat models studied. In one of the few human studies, Clarke et al. [72] demonstrated that human individuals with higher levels of physical activity also have significantly greater microbial diversity in their stool; specifically the Firmicutes to Bacteroidetes ratio was greater in professional male athletes (mean
BMI $=29 \mathrm{~kg} / \mathrm{m}^{2}$ ) compared to two control groups, one with an overall higher BMI (mean $31 \mathrm{~kg} / \mathrm{m}^{2}$ ) and one with an overall lower BMI (mean $23 \mathrm{~kg} / \mathrm{m}^{2}$ ), to exclude the effects of body weight. Overall, these studies suggest exercise increases gut microbiota diversity.

The influence of exercise training on the gut microbiome has also been examined in combination with nutritional manipulations [73, 75]. Evans [73] explored the effects of 12 weeks of exercise training in combination with either a high or low fat diet, and the development of diet-induced obesity in mice, against sedentary controls. At the end of the study period, sedentary rats fed the high-fat diet gained considerably more body fat than the other groups, while the high-fat exercise rats experienced similar weight gains to the low-fat, sedentary rats. Importantly, however, exercise alone increased the ratio of Firmicutes to Bacteroidetes, irrespective of diet. Queipo-Ortuno et al. [75] further explored the combined effects of diet and physical activity on microbiota in rats assigned to different diet and exercise combinations, which included either diet restriction or ad libitum eating, and also unrestricted ad libitum exercise access or no exercise access. Significant effects were found most notably with rats exposed to exercise and energy restriction resulting in significant decreases in the quantity of Bacteroidetes and Firmicutes compared to the ad libitum groups. These studies provide the rationale for evaluating habitual physical activity levels when exploring the gut microbiota, across different geographical settings.

\section{Applying the epidemiologic transition model to understand the interaction of the obese gut-microbiota to geographical dependent factors}

The aforementioned studies independently and collectively provide support for employing the epidemiologic model for studying the associations between the gut microbiota and the development of obesity, by allowing for the interplay between the individual and multiple (hierarchical) levels of causation or determinants (e.g. dietary habits, daily physical activity, socio-economic status, public health policy as well as access to health care). In fact, this model has been key to our understanding of obesity and also other chronic diseases in the modern world [39-41, 83-95]. However, the human gut microbiota and its implications for the obesity epidemic has just begun to be explored [49, 50, 77, 81]. Interestingly, and to the best of our knowledge, the microbiota has not been explored in relationship to the epidemiologic transition model. We, therefore, here focused this review on explaining our current understanding of the relationship between the gut microbiota and obesity, while considering some of the environmental factors of the host 
influencing the gut microbiota (of note, many other factors may contribute to the gut microbiota than discussed here). With exploring these variables through the epidemiologic transition model, we will be able to capture these interactions, and provide novel insight into the obesity epidemic.

\section{Conclusions}

An epidemiologic model can be utilized to elucidate causal relationships between the gut microbiota and external environment independently and collectively, and this model will help us understand the role of the gut microbiota in the obesity epidemic. Notably, it is become well established that environmental factors influences the human gut microbiota, but it is still unclear exactly what environmental factors influence the gut microbiota in the development of the obese-phenotype. Unless we could control for all the environmental factors of human populations living in different areas of the world, which is unethical and impractical, the only way to fundamentally address this question outside of animal models is with large cross-sectional studies with sites across the globe. Hence we propose the development of large, globallydistributed, human microbiota studies to explicitly disentangle the interaction between environmental factors and the obese-phenotype associated gut microbiota.

\section{Abbreviations}

WHO: World Health Organization; FTO: fat mass and obesity associated gene; HDI: human development index; US: United States; METS: Modeling the Epidemiologic Transition Study.

\section{Authors' contributions}

LRD and BTL conceived, designed and drafted the manuscript. MF and JG also contributed to the drafting of the manuscript. All authors read and approved the final manuscript.

\section{Author details \\ 1 Public Health Sciences, Stritch School of Medicine, Loyola University Chi- cago, 2160 S. 1st Ave, Maywood, IL 60153, USA. ${ }^{2}$ Division of Endocrinology, Metabolism and Molecular Medicine, Northwestern University, Evanston, USA. ${ }^{3}$ Argonne National Laboratory, Biosciences Department, Institute for Genomic and Systems Biology, 9700 South Cass Avenue, Argonne, IL 60439, USA. \\ ${ }^{4}$ Department of Ecology and Evolution, University of Chicago, 1101 E 57th Street, Chicago, IL 60637, USA. ${ }^{5}$ Marine Biological Laboratory, 7 MBL Street, Woods Hole, MA 02543, USA. ${ }^{6}$ College of Environmental and Resource Sci- ences, Zhejiang University, Hangzhou 310058, China. ${ }^{7}$ Jesse Brown Veterans Affairs Medical Center, Chicago, IL, USA.}

\section{Acknowledgements}

BTL is supported by the Department of Veterans Affairs, Veterans Health Administration, Office of Research and Development, Career Development (Grant no. 1IK2BX001587-01).

\section{Competing interests}

The authors declare that they have no competing interests.

Received: 20 June 2015 Accepted: 15 December 2015

Published online: 11 January 2016

\section{References}

1. Global Status Report on noncommunicable diseases 2014 World Health Organization. http://apps.who.int/iris/bitstr eam/10665/148114/1/9789241564854_eng.pdf.

2. Luke A, Bovet P, Plange-Rhule J, Forrester TE, Lambert EV, Schoeller DA, Dugas LR, Durazo-Arvizu RA, Shoham DA, Cao G, et al. A mixed ecologiccohort comparison of physical activity and weight among young adults from five populations of African origin. BMC Public Health. 2014;14:397.

3. Popkin BM, Adair LS, Ng SW. Global nutrition transition and the pandemic of obesity in developing countries. Nutr Rev. 2012;70(1):3-21.

4. Farni K, Shoham DA, Cao G, Luke AH, Layden J, Cooper RS, Dugas LR. Physical activity and pre-diabetes - an unacknowledged mid-life crisis: findings from NHANES 2003-2006. PeerJ. 2014;2:e499.

5. Peer N, Steyn K, Lombard C, Lambert EV, Vythilingum B, Levitt NS. Rising diabetes prevalence among urban-dwelling black South Africans. PLoS One. 2012;7(9):e43336.

6. Dietrich P, Hellerbrand C. Non-alcoholic fatty liver disease, obesity and the metabolic syndrome. Best Pract Res Clin Gastroenterol. 2014;28(4):637-53.

7. Pettitt DJ, Talton J, Dabelea D, Divers J, Imperatore G, Lawrence JM, Liese AD, Linder B, Mayer-Davis EJ, Pihoker C, et al. Prevalence of diabetes in U.S. youth in 2009: the SEARCH for diabetes in youth study. Diabetes Care. 2014;37(2):402-8.

8. Saydah S, Bullard KM, Cheng Y, Ali MK, Gregg EW, Geiss L, Imperatore G. Trends in cardiovascular disease risk factors by obesity level in adults in the United States, NHANES 1999-2010. Obesity. 2014;22(8):1888-95.

9. Swinburn B, Sacks G, Ravussin E. Increased food energy supply is more than sufficient to explain the US epidemic of obesity. Am J Clin Nutr. 2009;90(6):1453-6.

10. Hall KD, Sacks G, Chandramohan D, Chow CC, Wang YC, Gortmaker SL, Swinburn BA. Quantification of the effect of energy imbalance on bodyweight. Lancet. 2011;378(9793):826-37.

11. Chaput JP, Perusse L, Despres JP, Tremblay A, Bouchard C. Findings from the Quebec Family Study on the etiology of obesity: genetics and environmental highlights. Curr Obes Rep. 2014;3:54-66.

12. Locke AE, Kahali B, Berndt SI, Justice AE, Pers TH, Day FR, Powell C, Vedantam S, Buchkovich ML, Yang J, et al. Genetic studies of body mass index yield new insights for obesity biology. Nature. 2015;518(7538):197-206.

13. Luke A, Cooper RS, Prewitt TE, Adeyemo AA, Forrester TE. Nutritional consequences of the African diaspora. Annu Rev Nutr. 2001;21:47-71.

14. De Bourdeaudhuij I, Van Dyck D, Salvo D, Davey R, Reis RS, Schofield G, Sarmiento OL, Mitas J, Christiansen LB, MacFarlane D, et al. International study of perceived neighbourhood environmental attributes and body mass index: IPEN adult study in 12 countries. Int J Behav Nutr Phys Act. 2015;12:62.

15. Raymond SU, Leeder S, Greenberg HM. Obesity and cardiovascular disease in developing countries: a growing problem and an economic threat. Curr Opinion Clin Nutr Metab Care. 2006;9(2):111-6.

16. Karalius VP, Harbison JE, Plange-Rhule J, van Breemen RB, Li G, Huang K, Durazo-Arvizu RA, Mora N, Dugas LR, Vail L, et al. Bisphenol A (BPA) found in humans and water in three geographic regions with distinctly different levels of economic development. Environ Health Insights. 2014;8:1-3.

17. Kramer H, Dugas $L$, Shoham D. Obesity as an effect modifier of the risk of death in chronic kidney disease. Nephrol Dial Transpl. 2013;28(Suppl 4):iv65-72.

18. Desai M, Jellyman JK, Ross MG. Epigenomics, gestational programming and risk of metabolic syndrome. Int J Obes. 2015;39(4):633-41.

19. Rosenquist JN, Lehrer SF, O'Malley AJ, Zaslavsky AM, Smoller JW, Christakis NA. Cohort of birth modifies the association between FTO genotype and BMI. Proc Natl Acad Sci USA. 2015;112(2):354-9.

20. Ley RE, Turnbaugh PJ, Klein S, Gordon Jl. Microbial ecology: human gut microbes associated with obesity. Nature. 2006;444(7122):1022-3.

21. Turnbaugh PJ, Ley RE, Mahowald MA, Magrini V, Mardis ER, Gordon JI. An obesity-associated gut microbiome with increased capacity for energy harvest. Nature. 2006;444(7122):1027-31.

22. Ridaura VK, Faith JJ, Rey FE, Cheng J, Duncan AE, Kau AL, Griffin NW, Lombard V, Henrissat B, Bain JR, et al. Gut microbiota from twins discordant for obesity modulate metabolism in mice. Science. 2013;341(6150):1241214.

23. Turnbaugh PJ, Backhed F, Fulton L, Gordon J. Diet-induced obesity is linked to marked but reversible alterations in the mouse distal gut microbiome. Cell Host Microbe. 2008;3(4):213-23. 
24. Turnbaugh PJ, Hamady M, Yatsunenko T, Cantarel BL, Duncan A, Ley RE, Sogin ML, Jones WJ, Roe BA, Affourtit JP, et al. A core gut microbiome in obese and lean twins. Nature. 2009;457(7228):480-4.

25. Turnbaugh PJ, Gordon Jl. The core gut microbiome, energy balance and obesity. J Physiol. 2009;587(Pt 17):4153-8.

26. Ley RE. Obesity and the human microbiome. Curr Opin Gastroenterol. 2010;26(1):5-11.

27. Sonnenburg ED, Sonnenburg JL. Starving our microbial self: the deleterious consequences of a diet deficient in microbiota-accessible carbohydrates. Cell Metab. 2014;20(5):779-86.

28. Karlsson F, Tremaroli V, Nielsen J, Backhed F. Assessing the human gut microbiota in metabolic diseases. Diabetes. 2013;62(10):3341-9.

29. Karlsson FH, Nookaew I, Nielsen J. Metagenomic data utilization and analysis (MEDUSA) and construction of a global gut microbial gene catalogue. PLoS Comput Biol. 2014;10(7):e1003706.

30. Ley RE, Peterson DA, Gordon Jl. Ecological and evolutionary forces shaping microbial diversity in the human intestine. Cell. 2006;124(4):837-48.

31. Tyler AD, Smith MI, Silverberg MS. Analyzing the human microbiome: a "how to" guide for physicians. Am J Gastroenterol. 2014;109(7):983-93.

32. Smith MI, Turpin W, Tyler AD, Silverberg MS, Croitoru K. Microbiome analysis - from technical advances to biological relevance. F1000 Prime Rep. 2014;6:51.

33. Lax S, Smith DP, Hampton-Marcell J, Owens SM, Handley KM, Scott NM, Gibbons SM, Larsen P, Shogan BD, Weiss S, et al. Longitudinal analysis of microbial interaction between humans and the indoor environment. Science. 2014;345(6200):1048-52.

34. Kelley ST, Gilbert JA. Studying the microbiology of the indoor environment. Genome Biol. 2013;14(2):202.

35. Cox LM, Yamanishi S, Sohn J, Alekseyenko AV, Leung JM, Cho I, Kim SG, $\mathrm{Li} \mathrm{H}, \mathrm{Gao}$ Z, Mahana D, et al. Altering the intestinal microbiota during a critical developmental window has lasting metabolic consequences. Cell. 2014;158(4):705-21.

36. Ng M, Fleming T, Robinson M, Thomson B, Graetz N, Margono C, Mullany EC, Biryukov S, Abbafati C, Abera SF, et al. Global, regional, and national prevalence of overweight and obesity in children and adults during 1980-2013: a systematic analysis for the Global Burden of Disease Study 2013. Lancet. 2014;384(9945):766-81.

37. Stevens GA, Singh GM, Lu Y, Danaei G, Lin JK, Finucane MM, Bahalim AN, McIntire RK, Gutierrez HR, Cowan M, et al. National, regional, and global trends in adult overweight and obesity prevalences. Popul Health Metr. 2012;10(1):22

38. United Nations Development Programme. Human Development Index (HDI). http://hdr.undp.org/en/content/human-development-index-hdi.

39. Kaufman JS, Tracy JA, Durazo-Arvizu RA, Cooper RS. Lifestyle, education, and prevalence of hypertension in populations of African origin. Results from the International Collaborative Study on Hypertension in Blacks. Ann Epidemiol. 1997;7(1):22-7.

40. Kaufman JS, Durazo-Arvizu RA, Rotimi CN, McGee DL, Cooper RS. Obesity and hypertension prevalence in populations of African origin. The Investigators of the International Collaborative Study on Hypertension in Blacks. Epidemiology. 1996;7(4):398-405.

41. Cooper R, Forrester T, Ogunbiyi O, Muffinda J. Angiotensinogen levels and obesity in four black populations. ICSHIB Investigators. J Hypertens. 1998;16(5):571-5.

42. Cooper R, Rotimi C, Ataman S, McGee D, Osotimehin B, Kadiri S, Muna W, Kingue S, Fraser $\mathrm{H}$, Forrester $\mathrm{T}$, et al. The prevalence of hypertension in seven populations of west African origin. Am J Public Health. 1997;87(2):160-8.

43. Ezzati M, Vander Hoorn S, Lawes CM, Leach R, James WP, Lopez AD, Rodgers A, Murray CJ. Rethinking the "diseases of affluence" paradigm: global patterns of nutritional risks in relation to economic development. PLoS Med. 2005;2(5):e133.

44. Durazo-Arvizu RA, Luke A, Cooper RS, Cao G, Dugas L, Adeyemo A, Boyne M, Forrester T. Rapid increases in obesity in Jamaica, compared to Nigeria and the United States. BMC Public Health. 2008;8:133.

45. Cooper R, Rotimi C. Hypertension in blacks. Am J Hypertens. 1997;10(7 Pt 1):804-12.

46. Rotimi CN, Cooper RS, Marcovina SM, McGee D, Owoaje E, Ladipo M. Serum distribution of lipoprotein(a) in African Americans and Nigerians: potential evidence for a genotype-environmental effect. Genet Epidemiol. 1997:14(2):157-68.
47. Okosun IS, Liao Y, Rotimi CN, Choi S, Cooper RS. Predictive values of waist circumference for dyslipidemia, type 2 diabetes and hypertension in overweight White, Black, and Hispanic American adults. J Clin Epidemiol. 2000;53(4):401-8.

48. Okosun IS, Liao Y, Rotimi CN, Prewitt TE, Cooper RS. Abdominal adiposity and clustering of multiple metabolic syndrome in White, Black and Hispanic americans. Ann Epidemiol. 2000;10(5):263-70.

49. Yatsunenko T, Rey FE, Manary MJ, Trehan I, Dominguez-Bello MG, Contreras M, Magris M, Hidalgo G, Baldassano RN, Anokhin AP, et al. Human gut microbiome viewed across age and geography. Nature. 2012;486(7402):222-7.

50. Lee S, Sung J, Lee J, Ko G. Comparison of the gut microbiotas of healthy adult twins living in South Korea and the United States. Appl Environ Microbiol. 2011;77(20):7433-7.

51. David LA, Materna AC, Friedman J, Campos-Baptista MI, Blackburn MC, Perrotta A, Erdman SE, Alm EJ. Host lifestyle affects human microbiota on daily timescales. Genome Biol. 2014;15(7):R89.

52. Backhed F, Ding H, Wang T, Hooper LV, Koh GY, Nagy A, Semenkovich CF, Gordon Jl. The gut microbiota as an environmental factor that regulates fat storage. Proc Natl Acad Sci USA. 2004;101(44):15718-23.

53. Le Chatelier E, Nielsen T, Qin J, Prifti E, Hildebrand F, Falony G, Almeida M, Arumugam M, Batto JM, Kennedy S, et al. Richness of human gut microbiome correlates with metabolic markers. Nature. 2013;500(7464):541-6.

54. Ferrer M, Ruiz A, Lanza F, Haange SB, Oberbach A, Till H, Bargiela R, Campoy C, Segura MT, Richter M, et al. Microbiota from the distal guts of lean and obese adolescents exhibit partial functional redundancy besides clear differences in community structure. Environ Microbiol. 2013;15(1):211-26.

55. Patil DP, Dhotre DP, Chavan SG, Sultan A, Jain DS, Lanjekar VB, Gangawani J, Shah PS, Todkar JS, Shah S, et al. Molecular analysis of gut microbiota in obesity among Indian individuals. J Biosci. 2012;37(4):647-57.

56. Murphy EF, Cotter PD, Healy S, Marques TM, O'Sullivan O, Fouhy F, Clarke SF, O'Toole PW, Quigley EM, Stanton C, et al. Composition and energy harvesting capacity of the gut microbiota: relationship to diet, obesity and time in mouse models. Gut. 2010;59(12):1635-42

57. Arumugam M, Raes J, Pelletier E, Le Paslier D, Yamada T, Mende DR, Fernandes GR, Tap J, Bruls T, Batto JM, et al. Enterotypes of the human gut microbiome. Nature. 2011;473(7346):174-80.

58. Bell DS. Changes seen in gut bacteria content and distribution with obesity: causation or association? Postgrad Med. 2015;127(8):863-8.

59. Vrieze A, Van Nood E, Holleman F, Salojarvi J, Kootte RS, Bartelsman JF, Dallinga-Thie GM, Ackermans MT, Serlie MJ, Oozeer R et al. Transfer of intestinal microbiota from lean donors increases insulin sensitivity in individuals with metabolic syndrome. Gastroenterology. 2012;143(4):913-16. e917.

60. Everard A, Lazarevic V, Gaia N, Johansson M, Stahlman M, Backhed F, Delzenne NM, Schrenzel J, Francois P, Cani PD. Microbiome of prebiotictreated mice reveals novel targets involved in host response during obesity. ISME J. 2014;8(10):2116-30.

61. Cani PD, Possemiers S, Van de Wiele T, Guiot Y, Everard A, Rottier O, Geurts L, Naslain D, Neyrinck A, Lambert DM, et al. Changes in gut microbiota control inflammation in obese mice through a mechanism involving GLP2-driven improvement of gut permeability. Gut. 2009;58(8):1091-103.

62. Bleau C, Karelis AD, St-Pierre DH, Lamontagne L. Crosstalk between intestinal microbiota, adipose tissue and skeletal muscle as an early event in systemic low-grade inflammation and the development of obesity and diabetes. Diabetes Metab Res Rev. 2015;31(6):545-61.

63. Ding S, Chi MM, Scull BP, Rigby R, Schwerbrock NM, Magness S, Jobin C, Lund PK. High-fat diet: bacteria interactions promote intestinal inflammation which precedes and correlates with obesity and insulin resistance in mouse. PLoS One. 2010;5(8):e12191.

64. Backhed F, Ley RE, Sonnenburg JL, Peterson DA, Gordon JI. Host-bacterial mutualism in the human intestine. Science. 2005;307(5717):1915-20.

65. Bakker GJ, Zhao J, Herrema H, Nieuwdorp M. Gut microbiota and energy expenditure in health and obesity. J Clin Gastroenterol. 2015;49(Suppl 1):S13-9.

66. Lopez-Cepero AA, Palacios C. Association of the intestinal microbiota and obesity. P R Health Sci J. 2015;34(2):60-4.

67. Janssen AW, Kersten S. The role of the gut microbiota in metabolic health Faseb J. 2015;29(8):3111-23. 
68. Suzuki TA, Worobey M. Geographical variation of human gut microbial composition. Biol Lett. 2014;10(2):20131037.

69. Schnorr SL, Candela M, Rampelli S, Centanni M, Consolandi C, Basaglia G, Turroni S, Biagi E, Peano C, Severgnini M, et al. Gut microbiome of the Hadza hunter-gatherers. Nat Commun. 2014;5:3654.

70. Voreades N, Kozil A, Weir TL. Diet and the development of the human intestinal microbiome. Front Microbiol. 2014;5:494.

71. Petriz BA, Castro AP, Almeida JA, Gomes CP, Fernandes GR, Kruger RH, Pereira RW, Franco OL. Exercise induction of gut microbiota modifications in obese, non-obese and hypertensive rats. BMC Genom. 2014;15:511.

72. Clarke SF, Murphy EF, O'Sullivan O, Lucey AJ, Humphreys M, Hogan A, Hayes P, O'Reilly M, Jeffery IB, Wood-Martin R, et al. Exercise and associated dietary extremes impact on gut microbial diversity. Gut. 2014;63(12):1913-20.

73. Evans CC, LePard KJ, Kwak JW, Stancukas MC, Laskowski S, Dougherty J, Moulton L, Glawe A, Wang Y, Leone V, et al. Exercise prevents weight gain and alters the gut microbiota in a mouse model of high fat diet-induced obesity. PLoS One. 2014;9(3):e92193.

74. Matsumoto M, Inoue R, Tsukahara T, Ushida K, Chiji H, Matsubara N, Hara H. Voluntary running exercise alters microbiota composition and increases $n$-butyrate concentration in the rat cecum. Biosci Biotechnol Biochem. 2008;72(2):572-6.

75. Queipo-Ortuno MI, Seoane LM, Murri M, Pardo M, Gomez-Zumaquero JM, Cardona F, Casanueva F, Tinahones FJ. Gut microbiota composition in male rat models under different nutritional status and physical activity and its association with serum leptin and ghrelin levels. PLoS One. 2013;8(5):e65465.

76. Albenberg LG, Wu GD. Diet and the intestinal microbiome: associations, functions, and implications for health and disease. Gastroenterology. 2014;146(6):1564-72.

77. De Filippo C, Cavalieri D, Di Paola M, Ramazzotti M, Poullet JB, Massart S, Collini S, Pieraccini G, Lionetti P. Impact of diet in shaping gut microbiota revealed by a comparative study in children from Europe and rural Africa. Proc Natl Acad Sci USA. 2010;107(33):14691-6.

78. Walker AW, Ince J, Duncan SH, Webster LM, Holtrop G, Ze X, Brown $D$, Stares MD, Scott P, Bergerat A, et al. Dominant and diet-responsive groups of bacteria within the human colonic microbiota. ISME J. 2011;5(2):220-30

79. Lin A, Bik EM, Costello EK, Dethlefsen L, Haque R, Relman DA, Singh U. Distinct distal gut microbiome diversity and composition in healthy children from Bangladesh and the United States. PLoS One. 2013;8(1):e53838.

80. Ou J, Carbonero F, Zoetendal EG, DeLany JP, Wang M, Newton K, Gaskins HR, O'Keefe SJ. Diet, microbiota, and microbial metabolites in colon cancer risk in rural Africans and African Americans. Am J Clin Nutr. 2013;98(1):111-20.

81. Tyakht AV, Kostryukova ES, Popenko AS, Belenikin MS, Pavlenko AV, Larin AK, Karpova IY, Selezneva OV, Semashko TA, Ospanova EA, et al. Human gut microbiota community structures in urban and rural populations in Russia. Nat Commun. 2013:4:2469.

82. Bermon S, Petriz B, Kajeniene A, Prestes J, Castell L, Franco OL. The microbiota: an exercise immunology perspective. Exerc Immunol Rev. 2015;21:70-9
83. Cooper RS, Amoah AG, Mensah GA. High blood pressure: the foundation for epidemic cardiovascular disease in African populations. Ethn Dis. 2003;13(2 Suppl 2):S48-52

84. Cooper RS, Rotimi CN, Kaufman JS, Owoaje EE, Fraser H, Forrester T, Wilks R, Riste LK, Cruickshank JK. Prevalence of NIDDM among populations of the African diaspora. Diabetes Care. 1997;20(3):343-8.

85. Cooper RS, Wolf-Maier K, Luke A, Adeyemo A, Banegas JR, Forrester T, Giampaoli S, Joffres M, Kastarinen M, Primatesta P, et al. An international comparative study of blood pressure in populations of European vs. African descent. BMC Med. 2005;3:2.

86. Kaufman JS, Owoaje EE, James SA, Rotimi CN, Cooper RS. Determinants of hypertension in West Africa: contribution of anthropometric and dietary factors to urban-rural and socioeconomic gradients. Am J Epidemiol. 1996;143(12):1203-18.

87. Dugas LR, Bovet P, Forrester TE, Lambert EV, Plange-Rhule J, DurazoArvizu RA, Shoham D, Kroff J, Cao G, Cooper RS, et al. Comparisons of intensity-duration patterns of physical activity in the US, Jamaica and 3 African countries. BMC Public Health. 2014;14(1):882.

88. Luke AH, Rotimi CN, Cooper RS, Long AE, Forrester TE, Wilks R, Bennett FI, Ogunbiyi O, Compton JA, Bowsher RR. Leptin and body composition of Nigerians, Jamaicans, and US blacks. Am J Clin Nutr. 1998;67(3):391-6.

89. Luke A, Rotimi CN, Adeyemo AA, Durazo-Arvizu RA, Prewitt TE, MoragneKayser L, Harders R, Cooper RS. Comparability of resting energy expenditure in Nigerians and U.S. blacks. Obes Res. 2000;8(5):351-9.

90. Luke A, Guo X, Adeyemo AA, Wilks R, Forrester T, Lowe W Jr, Comuzzie AG, Martin LJ, Zhu X, Rotimi CN, et al. Heritability of obesity-related traits among Nigerians, Jamaicans and US black people. Int J Obes Relat Metab Disord. 2001;25(7):1034-41.

91. Luke A, Durazo-Arvizu RA, Rotimi CN, lams H, Schoeller DA, Adeyemo AA, Forrester TE, Wilks R, Cooper RS. Activity energy expenditure and adiposity among black adults in Nigeria and the United States. Am J Clin Nutr. 2002;75(6):1045-50.

92. Luke A, Durazo-Arvizu R, Rotimi C, Prewitt TE, Forrester T, Wilks R, Ogunbiyi OJ, Schoeller DA, McGee D, Cooper RS. Relation between body mass index and body fat in black population samples from Nigeria, Jamaica, and the United States. Am J Epidemiol. 1997;145(7):620-8.

93. Luke A, Dugas LR, Ebersole K, Durazo-Arvizu RA, Cao G, Schoeller DA, Adeyemo A, Brieger WR, Cooper RS. Energy expenditure does not predict weight change in either Nigerian or African American women. Am J Clin Nutr. 2009:89(1):169-76.

94. Luke A, Bovet P, Forrester TE, Lambert EV, Plange-Rhule J, Schoeller DA, Dugas LR, Durazo-Arvizu RA, Shoham D, Cooper RS, et al. Protocol for the modeling the epidemiologic transition study: a longitudinal observational study of energy balance and change in body weight, diabetes and cardiovascular disease risk. BMC Public Health. 2012;11:927.

95. Luke A, Adeyemo AA, Tayo B, Durazo-Arvizu RA, Schoeller DA, Leman C, Cooper RS. Energy expenditure, adiposity and weight gain in Yoruba and African-American women. Obes Rev. 2006;7(Supplement 2):AOP0183.

\section{Submit your next manuscript to BioMed Central and we will help you at every step:}

- We accept pre-submission inquiries

- Our selector tool helps you to find the most relevant journal

- We provide round the clock customer support

- Convenient online submission

- Thorough peer review

- Inclusion in PubMed and all major indexing services

- Maximum visibility for your research

Submit your manuscript at www.biomedcentral.com/submit

C Biomed Central 